\title{
Working
}

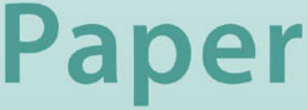




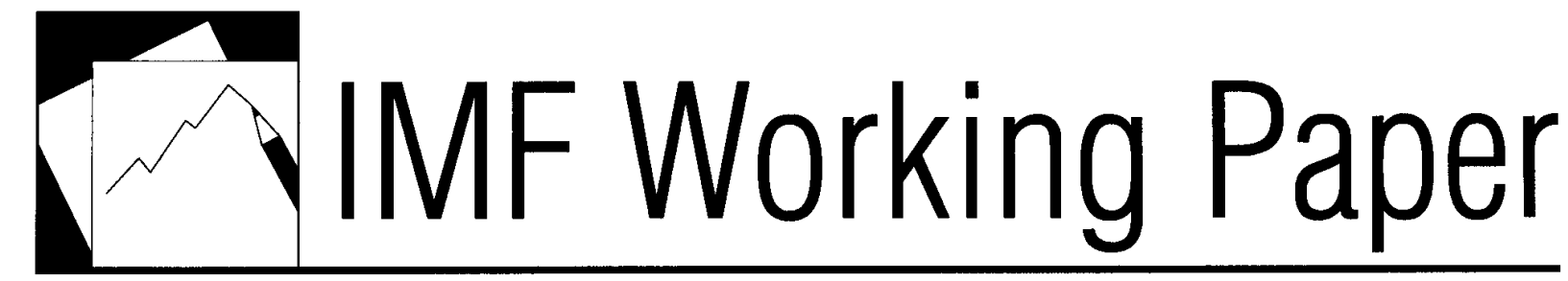

Stock-Flow Adjustments and Fiscal

Transparency: A Cross-Country Comparison

Anke Weber 
This page intentionally left blank

(C) International Monetary Fund. Not for Redistribution 


\title{
IMF Working Paper
}

Fiscal Affairs Department

\section{Stock-Flow Adjustments and Fiscal Transparency: A Cross-Country Comparison ${ }^{1}$ \\ Prepared by Anke Weber}

Authorized for distribution by Martine Guerguil

January 2012

\section{This Working Paper should not be reported as representing the views of the IMF.} The views expressed in this Working Paper are those of the author(s) and do not necessarily represent those of the IMF or IMF policy. Working Papers describe research in progress by the author(s) and are published to elicit comments and to further debate.

\begin{abstract}
Over the past three decades, large and persistent discrepancies between the annual change in public debt and the budget deficit, so-called stock-flow adjustments, were a prominent feature of debt dynamics in many economies. The aim of this paper is to investigate the underlying determinants of such discrepancies and their relationship with fiscal transparency using data for 163 countries. Results show that such discrepancies can only be partly explained by balance sheet effects and the realization of contingent liabilities and that significant differences exist in average stock-flow adjustments across countries reflecting country-specific factors. The more fiscally transparent the country, the smaller these tend to be. The contribution of stock-flow adjustments to increases in debt is likewise smaller in countries with above average fiscal transparency. This may not be coincidental, as a lack of fiscal transparency may make it easier for governments to engage in deceptive fiscal stratagems.
\end{abstract}

JEL Classification Numbers: H60, H63, F34

Keywords: Public Debt, Budget Deficits, Fiscal Transparency

Author's E-Mail Address: aweber@imf.org

\footnotetext{
${ }^{1}$ I would like to thank Carlo Cottarelli, Philip Gerson, Martine Guerguil, and Paolo Mauro for helpful comments and discussions. I am grateful to Ali Abbas, Nina Budina, Fuad Hasanov, Laura Jaramillo Mayor, Jahyun Koo, Philip Lane, and Marialuz Moreno-Badia for comments and suggestions. The main results of this paper were published in the IMF's September 2011 Fiscal Monitor. Petra Dacheva and Raquel Gomez Sirera provided excellent research assistance. All remaining errors are my own.
} 


\section{Contents}

I. Introduction

II. Stock-Flow Adjustments: Definition and Some Descriptive Cross-Country Evidence......... 4

III. The Role Of Stock-Flow Adjustments in Explaining Large Changes in Public Debt......... 1

IV. The Main Determinants of Stock-Flow Adjustments Over The Past Three Decades ......... $\underline{9}$

A. The Role of Financial Transactions ........................................................

B. Cross-Country Panel Regressions .......................................................

V. Stock-Flow Adjustments and Fiscal Transparency...................................................12

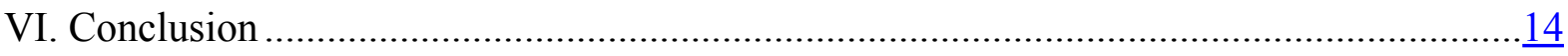

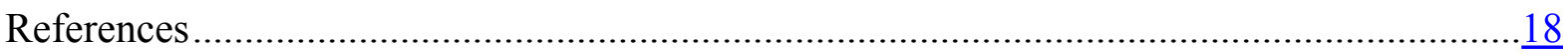

Tables

1. The Distribution of Stock-Flow Adjustments, 1980-2010 ...........................................

2. Advanced Economies: Transactions of Financial Assets, 1980-2010 .............................. $\frac{10}{11}$

3. Unbalanced Fixed Effects Panel Regressions 1980-2010 ...............................................11

Figures

1. Average Stock-Flow Adjustments

2. Accumulation of Stock-Flow Adjustments 1980-2010 ............................................

3. Decomposition of Large Episodes of Debt Changes ...................................................... $\frac{8}{9}$

4. Advanced Economies: Financial Assets Accumulation and Stock-Flow Adjustments......... $\underline{9}$

5. Fiscal Transparency and Fixed Effects .............................................................. 13

6. Fiscal Transparency and the Composition of Debt Increases, 1980-2010 .......................14

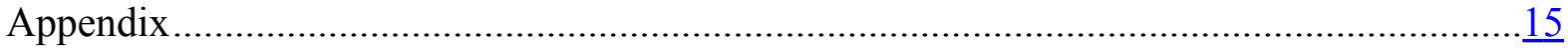

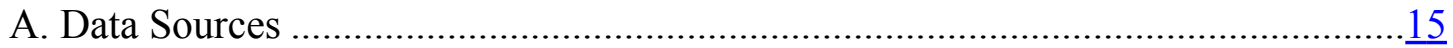

B. Additional Panel Regressions- Robustness Analysis .......................................

Appendix Tables

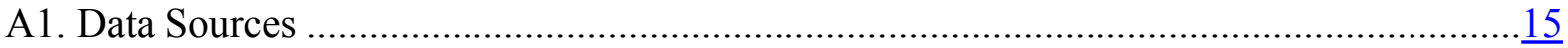

A2. Arellano-Bond Dynamic General Methods of Moments Panel Estimator ...................... 17 


\section{INTRODUCTION}

When public finances are strained governments might be tempted to engage in creative accounting in order to enable an increase in government liabilities without driving up the reported budget deficit. Such transactions could take the form of capital injections into public companies, thereby pushing spending to entities excluded from the fiscal accounts (IMF 2011a; Von Hagen and Wolff, 2006). This behavior would lead to persistent and positive discrepancies between the annual change in gross public debt and the budget deficit. Such discrepancies are commonly referred to as stock-flow adjustments, which, if positive, could lead to ex-post upward revisions of deficit levels. The aim of this paper is to investigate which factors are driving these discrepancies and whether they tend to be lower in countries that are more fiscally transparent. This analysis is carried out using data for 163 countries over the last three decades.

The existing literature has investigated the determinants of stock-flow adjustments in a cross country setting (Campos, Jaimovich and Panizza, 2006) and examined to what extent persistent discrepancies between annual changes in debt and budget deficits in Europe can be explained by accounting stratagems related to budget balance rules (Beetsma, Giuliodori, and Wierts, 2009; Von Hagen and Wolff, 2006). The present study is the first to focus on the relationship between stock-flow adjustments and fiscal transparency in a cross-country setting. Fiscal transparency is defined as openness toward the public at large about government structure and functions, fiscal policy intentions, public sector accounts and projections (IMF, 2007). In this paper it is measured by a specific index, which combines data from the IMF's Fiscal Transparency Report on Observance of Standards and Codes (see Hameed, 2005) and information on the quality of budget institutions compiled by DablaNorris et al (2010).

The paper finds that many countries recorded persistently positive and large stock-flow adjustments over the past three decades. Moreover, in most countries public debt stocks have increased more than their accumulated deficits over time, suggesting that stock-flow adjustments are a key determinant of debt dynamics. A decomposition of debt changes illustrates that over the last three decades, stock-flow adjustments were a significant source of debt increases, but played a minor role in explaining debt decreases. This asymmetry is surprising, as any number of factors - privatization, and the impact of exchange rate appreciation on the value of foreign currency liabilities, to name two-could lead to downward stock-flow adjustments to the debt. This finding is consistent with the view that government might engage in off-budget operations in order to hide the impact on the deficit of transactions that increase debt, while they are quite willing to let debt reducing measures pass through the budget. Reputational concerns associated with missing numerical budget balance targets, which historically have received more attention than public debt targets, might be one factor underlying this behavior.

Econometric analysis shows that stock-flow adjustments can be partly explained by balance sheet effects as well as the realization of contingent liabilities. However, average stock-flow adjustments show significant cross-country differences that cannot be accounted for by these factors and instead reflect country-specific factors (or fixed effects in regression analysis). The more fiscally transparent the country, the smaller these country-specific factors tend to 
be. The contribution of stock-flow adjustments to increases in debt is likewise smaller in countries with above average fiscal transparency. Fiscal transparency could play a significant role in reducing stock-flow adjustments by allowing more scrutiny of fiscal accounts and thus decreasing the ability of governments to use accounting stratagems and low-quality statistical systems.

The paper is organized as follows. Section II presents accounting identities as well as summary statistics. Section III investigates the sources of large debt changes and the contribution of stock-flow adjustments. Section IV looks at the determinants of these residual entities in greater detail. Section V investigates the relationship between fiscal transparency and stock-flow adjustments. Section VI concludes.

\section{Stock-Flow Adjustments: Definition And Some Descriptive Cross-Country EVIDENCE}

Stock-flow adjustments are defined as the difference between the annual change in gross debt and the budget deficit. This definition of stock-flow adjustments follows from the basic debt accumulation equation:

$$
\frac{\text { Debt }_{t}-D e b t_{t-1}}{N G D P_{t}}=\frac{\text { Deficit }_{t}}{N G D P_{t}}+\frac{S F_{t}}{N G D P_{t}},
$$

where Debt denotes gross public debt, Deficit denotes the overall budget deficit, $S F$ denotes the stock-flow adjustment and NGDP denotes nominal GDP. Alternatively, by splitting up the overall budget deficit into the primary budget deficit and interest expenditure, equation (1) can be rewritten as:

$\frac{D^{2 b t_{t}}}{N G D P_{t}}-\frac{\text { Debt }_{t-1}}{N G D P_{t-1}}=\frac{i_{t}-g_{t}}{1+g_{t}} \frac{D e b t_{t-1}}{N G D P_{t-1}}+\frac{\text { PrimaryDeficit }_{t}}{N G D P_{t}}+\frac{S F_{t}}{N G D P_{t}}$.

Equation (2) states that the change in the debt-to-GDP ratio is equal to the differential between the effective interest rate on debt $\left(i_{t}\right)$ and the nominal GDP growth rate $\left(g_{t}\right)$ multiplied by the lagged debt-to-GDP ratio plus the primary deficit and the stock-flow adjustment. The first term on the right hand side of equation (2), $\frac{i_{t}-g_{t}}{1+g_{t}}$, is also referred to as the interest-growth differential. The interest-growth differential, refers to the difference between interest rates - higher values of which raise the debt ratio by pushing up the overall deficit - and output growth rates, higher values of which reduce the debt to GDP ratio by raising the denominator. The larger the interest-growth differential, the faster is the growth of the debt ratio.

Stock-flow adjustments can arise for different reasons, including valuation effects through the impact of exchange rate changes on foreign currency denominated debt, time of recording effects (deficits are often measured in accrual terms while debt is a cash concept), and belowthe-line operations such as privatization and transactions in financial assets. While accounting issues can thus be expected to give rise to some stock-flow adjustments, large and persistent stock-flow adjustments could be the result of inappropriate recording of budgetary 
operations. If positive, they could lead to ex-post upward revisions of deficit levels (European Commission, 2003).

Data from the World Economic Outlook (WEO) database between 1980 and 2010, shows that stock-flow adjustments, on average, have been positive in advanced, emerging, and lowincome economies, with the latter exhibiting the largest residual entities on average (Figure 1). ${ }^{2}$ Weighted-average stock-flow adjustments exhibit certain peaks, several of which can be associated with major economic crises. For all three country groups, for example, the Great Recession is associated with a surge in these residual entities. For advanced economies, this could be caused by the substantial financial sector support provided during the recent crisis. Another factor could be a resurgence of accounting stratagems, given that public finances were strained and governments may have wanted to increase subsidies without driving up the reported deficits (IMF 2011a).

Figure 1. Average Stock-Flow Adjustments (Percent of GDP)

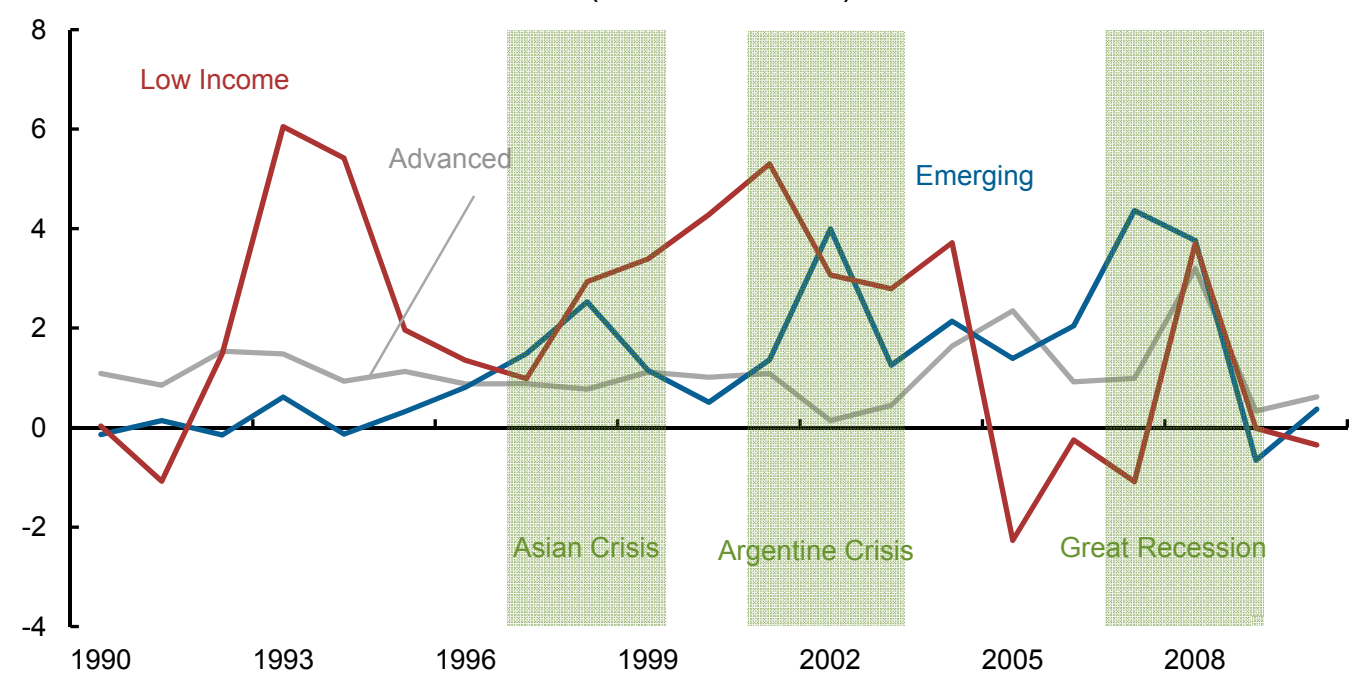

Sources: Country authorities; and IMF staff estimates.

Note: Weighted averages (GDP at PPP) with moving weights.

Perhaps not surprisingly the volatility of stock-flow adjustments is greatest in low-income countries (Table 1). Stock-flow adjustments in low-income economies range from negative 108.6 percent of GDP to 168.5 percent of GDP. These numbers reflect the impact of large outliers as some low-income economies have experienced significant debt relief and forgiveness (causing negative stock-flow adjustments) and exchange rate depreciations with a large share of public debt held in foreign currency (resulting in positive stock-flow adjustments).

\footnotetext{
${ }^{2}$ Detailed data sources are provided in Table A.1 in the Appendix. Economy groupings follow the classification in the IMF September 2011 Fiscal Monitor (IMF, 2011b).
} 
Table 1. The Distribution of Stock-Flow Adjustments, 1980-2010 (Percent of GDP)

\begin{tabular}{llrrrrrr}
\hline Country Group & Sample & Mean & Std & Min & Max & $N$ & Obs \\
\hline All countries & All & 2.8 & 11.4 & -108.6 & 168.5 & 163 & 2364 \\
& Without outliers* $^{*}$ & 2.6 & 6.5 & -15.8 & 30.8 & 163 & 2270 \\
& & & & & & & \\
Advanced & All & 2.3 & 4.9 & -9.8 & 44.0 & 34 & 705 \\
& Without outliers* $^{*}$ & 2.0 & 3.6 & -4.1 & 18.3 & 34 & 677 \\
& & & & & & & \\
Emerging & All & 2.9 & 9.1 & -36.5 & 103.1 & 68 & 905 \\
& Without outliers $^{*}$ & 2.5 & 5.7 & -9.5 & 27.3 & 67 & 869 \\
& & & & & & & \\
Low-Income & All & 3.2 & 16.9 & -108.6 & 168.5 & 61 & 754 \\
& Without outliers $^{*}$ & 3.0 & 10.6 & -32.5 & 42.9 & 61 & 724 \\
\hline
\end{tabular}

Sources: Country authorities; and IMF staff estimates.

Notes: * Outliers are the top and bottom 2 percentiles of the stock-flow adjustments.

Std denotes the standard deviation, $\mathrm{N}$ the number of countries, and Obs the number of observations.

It is also possible to investigate to what extent the increase in public debt stocks in most countries in recent years reflects past deficits. Figure 2 depicts the difference between the debt level in 2010 and the sum of the initial debt level in 1980 and accumulated deficits between 1981 and 2010 divided by 2010 nominal GDP. It shows that in almost all countries, public debt stocks have increased more than their accumulated deficits over the past three decades. ${ }^{3}$ Out of the total sample of 163 economies ( 34 advanced, 68 emerging and 61 lowincome), only 38 ( 5 advanced, 11 emerging and 22 low-income) register negative cumulative stock-flow adjustments between 1981 and 2010. This finding does not change significantly when the period ends in 2007 (only 41 economies --5 advanced, 14 emerging and 22 lowincome-- do not experience higher gross-debt-to GDP ratios than can be accounted for by their accumulated deficits and initial debt-to-GDP ratios). Thus, most countries had already experienced persistent positive stock-flow adjustments prior to the crisis period of 2008 to 2010. The higher prevalence of negative cumulative stock-flow adjustments in low-income economies, compared to advanced and emerging economies, is likely the result of extensive debt relief and forgiveness.

\footnotetext{
${ }^{3}$ For countries where gross debt and budget deficit data are not available from 1980 onwards, the earliest available year is used.
} 
Figure 2. Accumulation of Stock-Flow Adjustments 1980-

2010

(in percent of 2010 GDP)

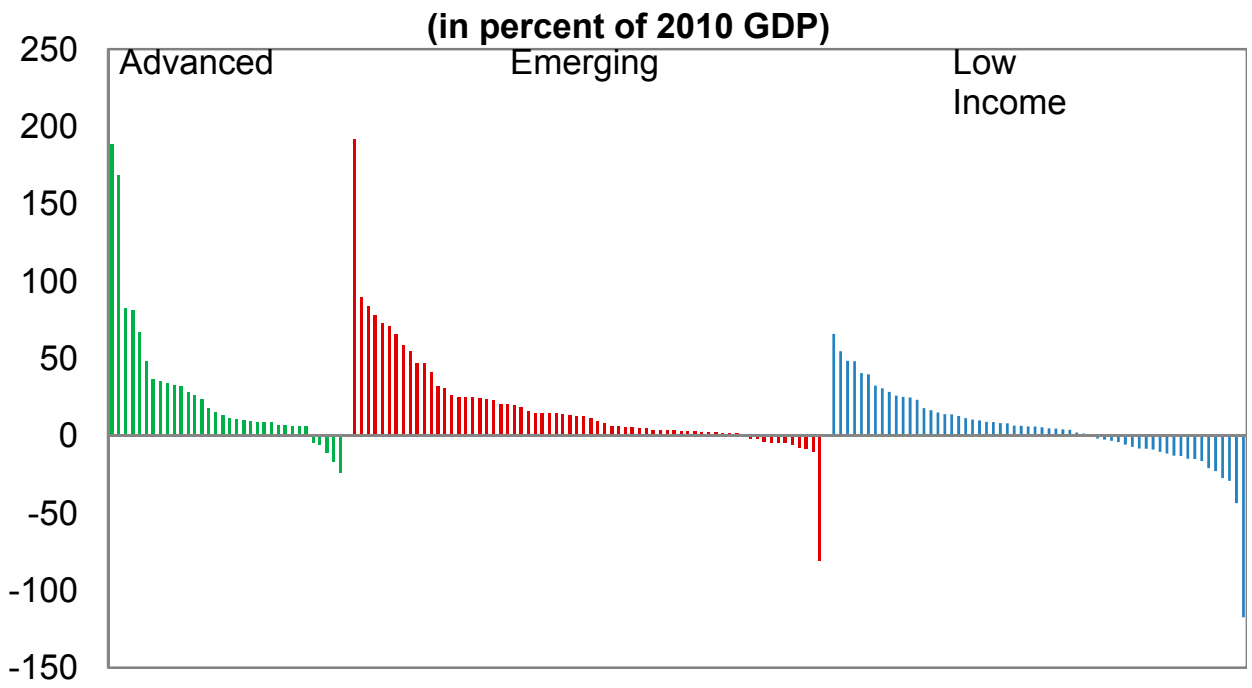

Sources: Country authorities; and IMF staff estimates.

\section{The Role Of Stock-Flow AdJUSTMEnTS In EXPlaining LaRge Changes IN Public DebT}

Following the methodology outlined in Abbas et al. (2011), major episodes of debt changes are defined as changes of more than 10 percentage points in the gross public debt-to-GDP ratios while allowing temporary reversals. This allows focusing on sustained changes in the public debt ratio, ignoring intermediate interruptions that are short or small in relation to the duration and size of the episode defined. Debt changes during the identified episodes are then decomposed into their determinants according to equation (2) namely, the primary deficit, the interest-growth differential, and the stock-flow adjustment.

Between 1980 and 2010, stock-flow adjustments were a significant source of debt increases, while they played only a minor role in explaining debt decreases (Figure 3). The average debt increase for country groups ranged from 25 percent of GDP in advanced economies to 33 percent of GDP in low-income economies. More than half of the average debt increase was explained by stock-flow adjustments. While primary deficits accounted for a substantial amount of debt increases in advanced economies, their contribution was smaller in emerging and low-income economies. The average debt decrease ranged from 18 percentage points of GDP in advanced to 62 percentage points of GDP in low-income economies. While in advanced economies, primary surpluses were the main contributor to debt reductions, in emerging and low-income economies, the combination of rapid output growth and low interest rates accounted for most of the debt decreases.

The asymmetry in the role of stock-flow adjustments in debt increases and debt decreases is somewhat surprising since a number of factors - privatization, or the impact of exchange rate appreciation on the value of foreign currency liabilities, to name two - could lead to downward stock-flow adjustments to the debt. It is consistent with the view that governments may succumb to the temptation to engage in off-budget transactions to hide the impact of 
transactions that would increase the debt, but are quite willing to have debt-reducing measures pass through the budget. Reputational and other costs associated with missing publicly announced deficit targets, which historically have received more attention than public debt targets, could be one factor motivating this behavior.

Figures 3. Decomposition of Large Episodes of Debt Changes (Percent of GDP)

\section{Sources of Debt Increases over Time}

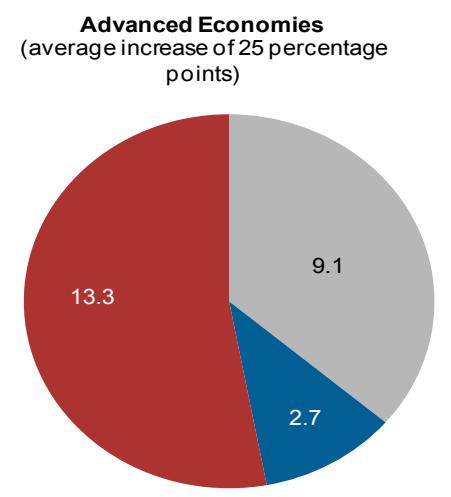

Primary deficit
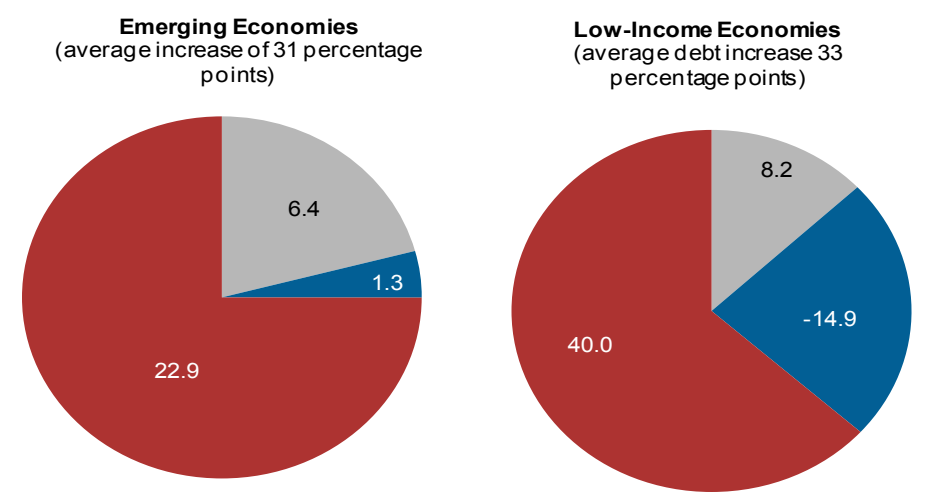

Low-Income Economies erage debt increase 33 percentage points)

- Stock-flow adjustment

\section{Sources of Debt Decreases over Time}

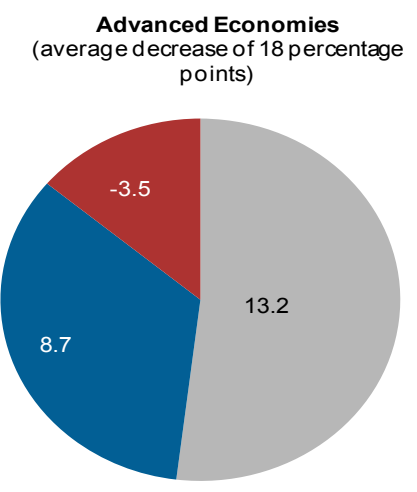

- Primary surplus

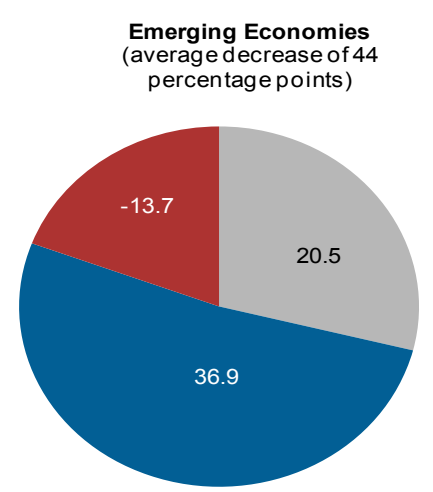

Interest-growth differential

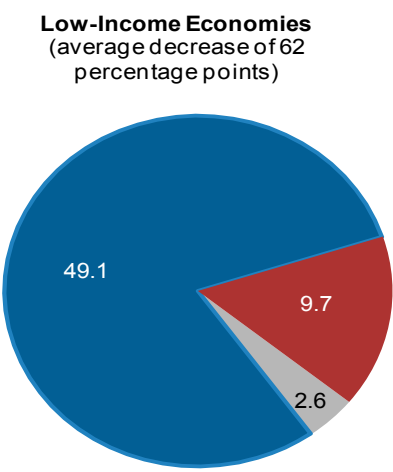

-Stock-flow adjustment

Sources: Country authorities; and IMF staff estimates. 


\section{The Main Determinants of Stock-Flow Adjustments OVer the Past Three DECADES}

In principle, stock-flow adjustments could be due to a large number of factors, some perfectly legitimate, including accounting issues. This section will therefore investigate their determinants in more detail. It examines first the role of the acquisition of financial assets in causing stock-flow adjustments. Owing to data availability, this analysis focuses on the advanced economies. Cross country panel regressions then look the role of contingent liabilities and balance sheet effects.

\section{A. The Role of Financial Transactions}

One important difference between the overall deficit and gross debt is that the latter includes financial transactions. The difference between gross and net debt data provides a measure of the magnitude of these below-the-line transactions, since government assets are netted from liabilities when compiling net debt data.

Data on net debt for emerging and low-income economies are scarce. For a majority of advanced economies for which data are available, changes in financial assets account for a large proportion of stock-flow adjustments (Figure 4). Countries may invest their budget surpluses into financial assets instead of paying back debt. However, in countries with numerical budget balance rules, which have often received more attention than debt rules, governments may have an incentive to shift expenditure below the line in order to avoid breaching the deficit limit. These transactions could take the form of capital injections into public companies, thereby pushing spending to entities excluded from the fiscal accounts (IMF 2011a; Von Hagen and Wolff, 2006).

Figure 4. Advanced Economies: Financial Assets Accumulation and Stock-Flow Adjustments

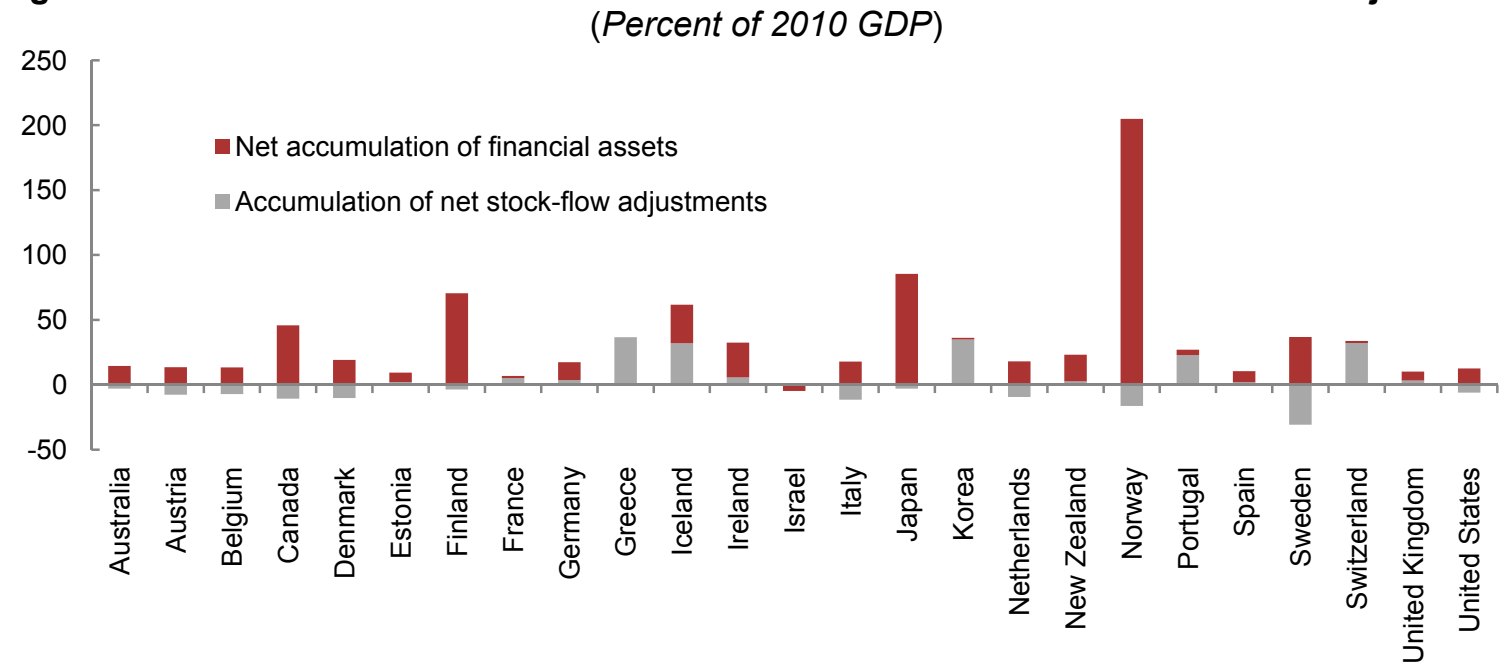

Sources: Country authorities; and IMF staff calculations. For Iceland, the country authorities' definition of the overall fiscal balance is used after 1998.

Notes: The accumulation of net stock-flow adjustments measures the sum of net stock-flow adjustments between 1981 and 2010, as a percentage of 2010 GDP. Net stock-flow adjustments are defined as the difference between the change in the level of annual net debt minus the overall budget balance (in levels). Thus, they measure gross stock-flow adjustments net of transactions in financial assets. The net accumulation of financial assets then corresponds to the difference between cumulative gross stock-flow adjustments and net stock-flow adjustments. 
A large majority of transactions in financial assets in advanced economies have been positive over the last three decades (Table 2). Excluding banking crises, about one-third of financial asset accumulations occurred in countries that were experiencing budget surpluses on average and had relatively small debt levels (Denmark, Estonia, Finland, Korea, Norway, New Zealand, and Sweden). Another third took place in countries with numeric budget balance rules that were experiencing deficits at the same time. ${ }^{4}$ Thus there were a number of episodes during which countries may have had an incentive to revert to creative accounting practices. $^{56}$

Table 2. Advanced Economies: Transactions of Financial Assets, 1980-2010 (Percent of GDP)

\begin{tabular}{lrrr}
\hline & Mean & $N$ & Obs \\
\hline All transactions (accumulations and decumulations) & 2.0 & 25 & 559 \\
Accumulations & 3.6 & 25 & 411 \\
Accumulations excluding banking crises & & & \\
All & 3.5 & 25 & 370 \\
Surplus countries & 6.8 & 7 & 97 \\
Numeric budget balance rules and deficit & 2.0 & 14 & 94 \\
\hline
\end{tabular}

Sources: Country authorities; Fiscal Rules database by the IMF's Fiscal Affairs Department; Fiscal Policy and Surveillance Division (2009); and IMF staff calculations.

Notes: $\mathrm{N}$ denotes the number of countries and Obs the total number of observations. Surplus countries include Denmark, Estonia, Finland, Korea, Norway, New Zealand and Sweden.

\section{B. Cross-Country Panel Regressions}

Besides transactions in financial assets, there are several other potential sources of stock-flow adjustments such as valuation effects and debt forgiveness and reduction, especially in emerging and low-income economies. This section investigates these determinants in more detail by running cross-country fixed effects panel regressions including these factors as explanatory variables.

Results from fixed effects panel regressions suggest that for the advanced economies, fiscal costs arising from banking crises significantly contributed to stock-flow adjustments over 1980-2010. Since data are only available for overall fiscal costs for the entire duration of banking crises, annual fiscal costs are approximated by splitting total costs equally over the duration of the crisis. This approximation makes a regression rather than accounting approach necessary. Valuation effects - primarily, changes in the domestic currency value of the public debt stock arising from exchange rate fluctuations - do not play a significant role

\footnotetext{
${ }^{4}$ Of course, countries may wish to be "creative" even without numeric budget rules. The number of episodes reported in Table 2 during which countries may have had an incentive to revert to creative accounting is thus likely to be underestimated.

${ }^{5}$ See IMF 2011a for examples of accounting stratagems applied by some governments.

${ }^{6}$ A natural test to check for the use of creative accounting practices in the form of employing public corporations as tools of fiscal policies would be to check their financial statements. Unfortunately data are not widely available to investigate this.
} 
in explaining stock-flow adjustments in the advanced economies, given that in most advanced economies the proportion of public debt held in foreign currency is now negligible. In emerging and low-income economies, on the other hand, banking crises, valuation effects and debt forgiveness or reduction were the main determinants of stock-flow adjustments (Table 3). These findings are robust to alternative specifications in which changes in debt as a percent of GDP are regressed on the budget balance and the same explanatory variables as above (see Appendix B). The analysis uses an instrumental variable approach as suggested by Arellano and Bond (1991) in order to make sure that the results are not biased by possible endogeneity and reverse causality among variables.

\section{Table 3. Unbalanced Fixed Effects Panel Regressions 1980-2010, with Stock-Flow Adjustments as the Dependent Variable ${ }^{7}$} (Percent of GDP)

\begin{tabular}{lcc}
\hline & Advanced & $\begin{array}{c}\text { Emerging and Low- } \\
\text { Income }\end{array}$ \\
\hline Constant & -0.89 & 1.66 \\
Inflation & $(0.47)^{*}$ & $(0.38)^{\star * *}$ \\
Valuation effect & 0.06 & 0.18 \\
& $(0.06)$ & $(0.03)^{\star * *}$ \\
Debt forgiveness or reduction (percent of GDP) & 0.00 & 0.75 \\
& $(0.00)$ & $(0.06)^{\star * *}$ \\
Banking crises & & -0.46 \\
& & $(0.06)^{\star * *}$ \\
R-squared (within) & 5.33 & 3.92 \\
R-squared with country fixed effects & $(0.70)^{\star * *}$ & $(1.84)^{\star *}$ \\
Observations & & 0.19 \\
Number of countries & 0.17 & 0.24 \\
\hline
\end{tabular}

Sources: World Economic Outlook; World Bank Global Development Finance Database; OECD; IFS; and IMF Financial Crisis Episodes Database (Laeven and Valencia, 2010).

Notes: The definition of stock-flow adjustments follows from the basic debt accumulation equation:

$$
\frac{D e b t_{\mathrm{i}}-D e b t_{\mathrm{i}-\mathrm{i}}}{N O D F_{1}}=\frac{D e f i v t_{\mathrm{i}}}{N O D F_{\mathrm{t}}}+\frac{S F_{\mathrm{i}}}{N O D R_{2}}
$$

where Debt denotes net debt for the advanced economies and gross debt for the emerging and low-income economies, Deficit denotes the overall budget deficit, $S F$ denotes the stock-flow adjustment, and NGDP denotes nominal GDP.

Robust standard errors in parentheses; * denotes significance at 10 percent level; ${ }^{* *}$ denotes significance at 5 percent; ***denotes significance at 1 percent.

Valuation effect denotes the percentage change in the real effective exchange rate interacted with the public sector debt denoted in foreign currency (in percent of GDP); a positive change denotes exchange rate depreciation.

Debt forgiveness or reduction refers to the total amount of debt (in percent of GDP) that is forgiven or reduced.

In the advanced economies, banking crises denotes the total fiscal costs of a particular banking crisis spread equally over its duration. Banking crises for the emerging and low-income economies, for which detailed data on fiscal costs is not as widely available, is a dummy variable that takes a value of 1 during a banking crisis.

\footnotetext{
${ }^{7}$ A Hausman (1978) test was conducted for both the advanced and emerging/low-income countries regressions to check whether a fixed effects model is preferable to a random effects model. The hypothesis that the individual-level effects are adequately captured by a random effects model can be rejected at the 1 percent level of significance.
} 
However, significant differences arise in the average stock-flow adjustments across countries that cannot be explained by the included variables but instead reflect country-specific characteristics ("country fixed effects" in regression analysis). These fixed effects explain about 12 percent of the variance in stock-flow adjustments in advanced economies and 24 percent in emerging and low-income economies. They could reflect the fact that measurement issues are more important in some countries than others, or that some governments are more inclined to revert to creative accounting practices in order to circumvent fiscal rules. The next section will investigate whether these fixed effects tend to be lower in countries that are more fiscally transparent.

\section{StOCK-FLOW AdJUSTMEnTS AND FisCal Transparency}

Greater fiscal transparency - defined as openness toward the public at large about government structure and functions, fiscal policy intentions, public sector accounts, and projections (IMF, 2007) - allows better scrutiny of government accounts and would thus make it harder for government to engage in deceptive fiscal stratagems. It should also enhance the quality of fiscal data and thereby decrease stock-flow adjustments arising from measurement issues. This section examines the relationship between stock-flow adjustments and fiscal transparency.

In order to perform this analysis, this paper makes use of two sources of data on fiscal transparency: the fiscal transparency Report on Observance of Standards and Codes (ROSC, see Hameed, 2005); and the quality of budget institutions index developed by Dabla-Norris and others (2010), which includes a transparency index of budget institutions as one category. The constructed index does not track the evolution of transparency over time but merely provides an index for each country at a particular point in time (around 2009 for most countries). The ROSC transparency index provides data for 90 countries including advanced economies, whereas the index by Dabla-Norris et al. (2010) provides data for 72 low-income and emerging economies. For 41 emerging and low-income economies, both sources of data are available. Using those common observations to make some judgment on the comparability of the two indices, the two data sources are merged by calculating the average difference between the two indices for those observations that are available and then adding this to the ROSC index. ${ }^{8}$ This enables the construction of a broader cross country dataset that can be used in a signle regression analysis.

In general, greater fiscal transparency is associated with lower values of the fixed effects obtained from the cross-country regressions in Section IV. Cross-country regression results show a significant relationship between those fixed effects and transparency, with about 19 percent of the variation of the dependent variable explained by the regression (Regression 1 in Figure 5). This finding is robust to an alternative specification, which uses an automated STATA procedure that removes outliers based on leverage (a measure of how far an independent variable deviates from its mean) and residual in the equation (Regression 2 in

\footnotetext{
${ }^{8}$ The final dataset includes 87 countries for which data on fixed effects and fiscal transparency are available.
} 
Figure 5). To some extent this result is due to fiscal transparency being higher in advanced economies than in emerging economies and low-income countries, and, correspondingly, their country fixed effects being lower. However, even when performing the same analysis for emerging and low-income economies only, for which the average value of the constructed transparency index is about the same, results show a significantly negative relationship between fiscal transparency and the fixed effects from cross-country panel regressions (Regression 3 in Figure 5).

Figure 5. Fiscal Transparency and Fixed Effects

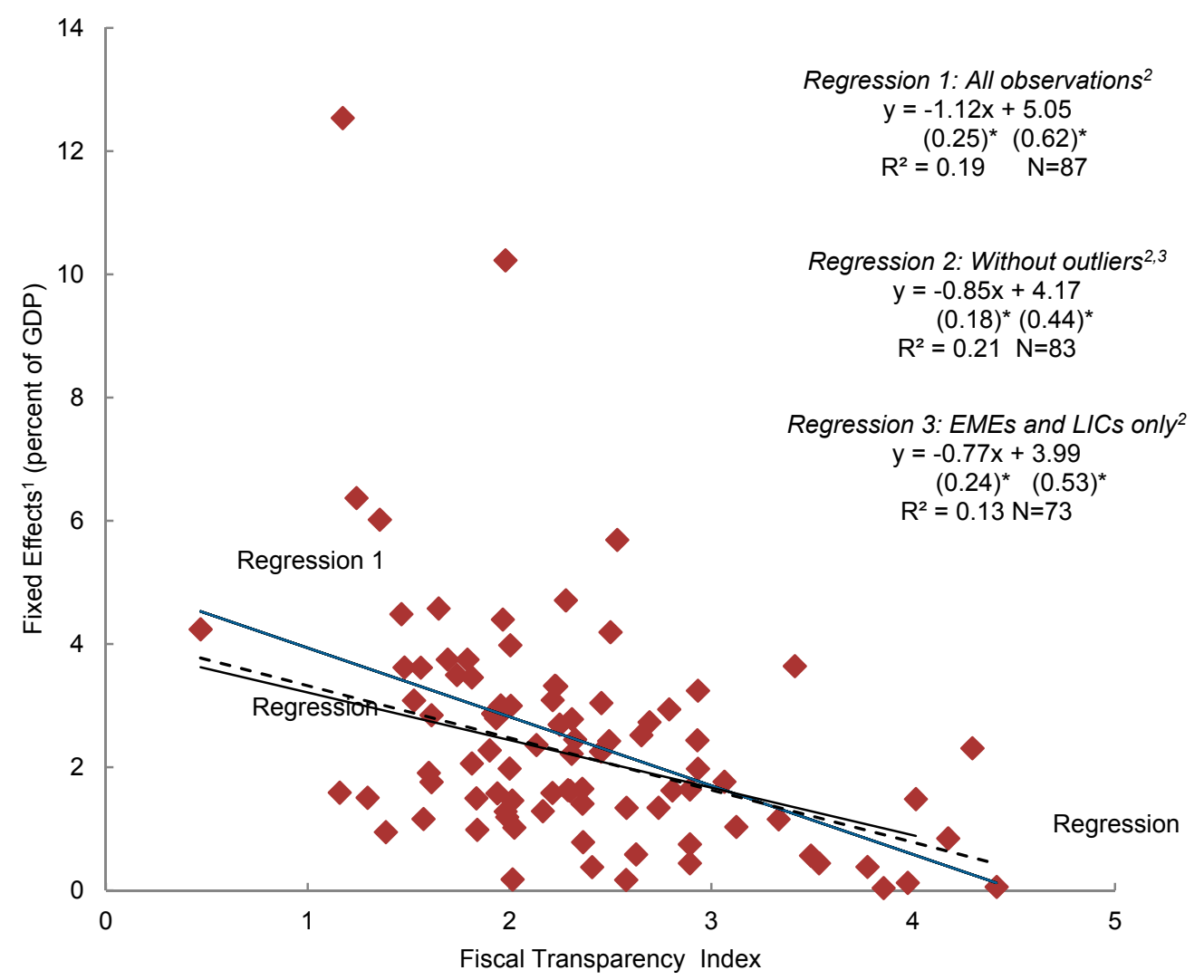

Sources: IMF staff calculations.

Note: Higher values of the fiscal transparency index denote greater fiscal transparency.

$1 /$ Absolute values of fixed effects for each country from panel regressions summarized in Table A1.3.

$2 /$ Standard errors in parentheses. * denotes significance at the 1 percent level.

3/ Outliers are removed using an automated STATA procedure based on leverage (a measure of how far an independent variable deviates from its mean) and residual in the equation.

Like in Section III, it is possible to look at the contribution of stock-flow adjustments to debt changes comparing countries that experience above and below average fiscal transparency. Average transparency simply refers to the average of the constructed transparency index for 87 economies. The average debt increase is again decomposed into its determinants according to equation (2) namely, the primary deficit, the interest-growth differential, and the stock-flow adjustment. Interestingly, in countries with above average fiscal transparency the contribution of stock-flow adjustments to increases in debt is significantly smaller than in 
countries with below average fiscal transparency. This is true both for advanced and emerging and low-income economies (Figure 6).

Figure 6. Fiscal Transparency and the Composition of Debt Increases, 1980-2010

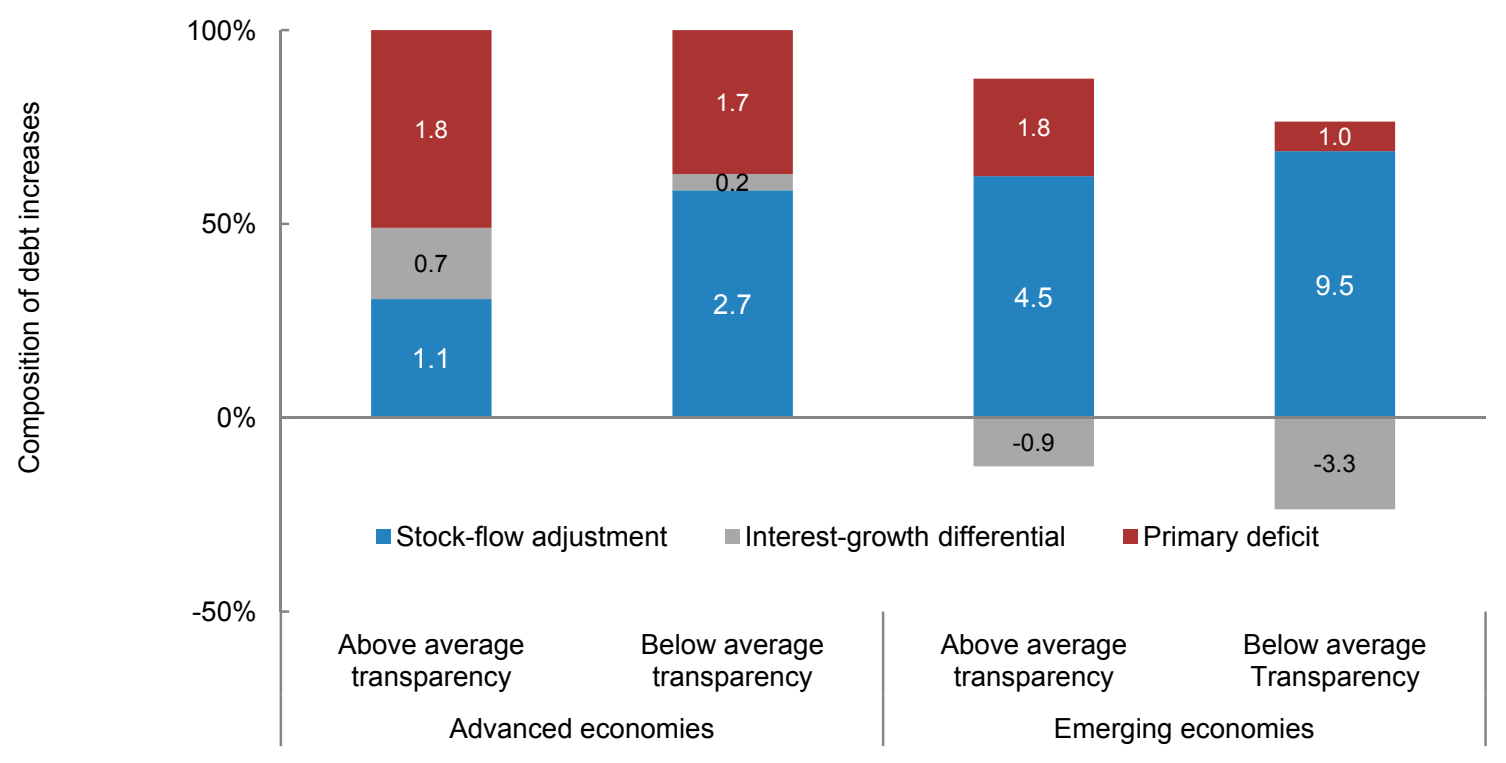

Source: IMF staff calculations.

Note: Debt increases denote any positive change in gross debt between 1980 and 2010. Data labels denote the mean of the components of debt increases for advanced, emerging, and low-income economies. Higher values of the transparency index denote greater fiscal transparency. Above (below) average denotes group of countries with a fiscal transparency index above (below) the average of its peer group (advanced or emerging economies).

Fiscal transparency allows better scrutiny of fiscal accounts and thus could decrease the ability of governments to use accounting stratagems and low-quality statistical systems, thereby lowering stock-flow adjustments. However, caution is needed when interpreting these results since causation could also run in the other direction, in that governments that are not subject to these political incentives and data limitations may be more willing to be fiscally transparent.

\section{Conclusion}

Over the last three decades, there have been many episodes of large discrepancies between the annual change in gross debt and the budget deficit. These discrepancies, so-called stockflow adjustments, were often positive and persistent, and public debt stocks are now higher in many countries than their accumulated deficits over time imply. Some of these discrepancies may have perfectly legitimate reasons. In fact, some differences between the annual change in gross debt and the budget deficit are to be expected owing to accounting issues. However, this paper finds some evidence that significant differences exist in average stock-flow adjustments across countries that cannot be explained by these factors and instead reflect country-specific characteristics. Moreover, these country-specific factors tend to be higher in countries with below average fiscal transparency suggesting that a lack of fiscal transparency may make it easier for governments to engage in deceptive fiscal stratagems. 


\section{APPENDIX}

\section{A. Data Sources}

Data from the World Economic Outlook Database (WEO) are calendar year general government data. Data span the period from 1980 to 2010 (based on availability).

Table A.1. Data Sources

\begin{tabular}{|c|c|c|}
\hline Variable & Details & Source \\
\hline Overall Fiscal Balance & $\begin{array}{l}\text { Net lending/borrowing, defined as } \\
\text { the difference between revenue } \\
\text { and total expenditure, using the } \\
2001 \text { edition of the IMF's } \\
\text { Government Finance Statistics } \\
\text { Manual (GFSM 2001). Does not } \\
\text { include policy lending. For some } \\
\text { countries, the overall balance } \\
\text { continues to be based on GFSM } \\
1986 \text {, which is defined as total } \\
\text { revenue and grants minus total } \\
\text { expenditure and net lending. In } \\
\text { national currency }\end{array}$ & $\begin{array}{l}\text { IMF World Economic Outlook } \\
\text { (WEO), June } 2011\end{array}$ \\
\hline Gross Debt & $\begin{array}{l}\text { All liabilities that require future } \\
\text { payment of interest and/or } \\
\text { principal by the debtor to the } \\
\text { creditor. This includes debt } \\
\text { liabilities in the form of SDRs, } \\
\text { currency and deposits; debt } \\
\text { securities; loans; insurance, } \\
\text { pension and standardized } \\
\text { guarantee schemes; and other } \\
\text { accounts payable. (See GFSM } \\
2011 \text { and Public Sector Debt } \\
\text { Statistics Manuals). The phrase } \\
\text { public debt is used in this } \\
\text { document interchangeably. } \\
\text { National Currency }\end{array}$ & $\begin{array}{l}\text { IMF World Economic Outlook } \\
\text { (WEO), June } 2011\end{array}$ \\
\hline Net Debt & $\begin{array}{l}\text { Gross debt minus financial } \\
\text { assets, including those held by } \\
\text { the broader public sector: for } \\
\text { example, social security funds } \\
\text { held by the relevant component of } \\
\text { the public sector, in some cases. } \\
\text { In national currency }\end{array}$ & $\begin{array}{l}\text { IMF World Economic Outlook } \\
\text { (WEO), June } 2011\end{array}$ \\
\hline Nominal GDP & National Currency and US\$. & $\begin{array}{l}\text { IMF World Economic Outlook } \\
\text { (WEO), June } 2011\end{array}$ \\
\hline Net Interest Payments & $\begin{array}{l}\text { Interest expenditure minus } \\
\text { interest revenue }\end{array}$ & $\begin{array}{l}\text { IMF World Economic Outlook } \\
\text { (WEO), June } 2011\end{array}$ \\
\hline Primary Balance & $\begin{array}{l}\text { Overall balance excluding net } \\
\text { interest payment }\end{array}$ & $\begin{array}{l}\text { IMF World Economic Outlook } \\
\text { (WEO), June } 2011\end{array}$ \\
\hline Inflation & $\begin{array}{l}\text { Annual change in the consumer } \\
\text { price index in percent }\end{array}$ & $\begin{array}{l}\text { IMF World Economic Outlook } \\
\text { (WEO), June } 2011\end{array}$ \\
\hline
\end{tabular}




\begin{tabular}{|c|c|c|}
\hline Variable & Details & Source \\
\hline $\begin{array}{l}\text { Numerical Budget balance } \\
\text { rule }\end{array}$ & $\begin{array}{l}\text { Dummy variable which takes the } \\
\text { value of one for each year in } \\
\text { which such a rule exists in a } \\
\text { country. }\end{array}$ & $\begin{array}{l}\text { Fiscal Rules database by the } \\
\text { IMF's Fiscal Affairs } \\
\text { Department; Fiscal Policy and } \\
\text { Surveillance Division (2009). }\end{array}$ \\
\hline $\begin{array}{l}\text { Real Effective Exchange } \\
\text { Rate }\end{array}$ & $\begin{array}{l}\text { Real effective exchange rates } \\
\text { take account of price level } \\
\text { differences between trading } \\
\text { partners. Movements in real } \\
\text { effective exchange rates provide } \\
\text { an indication of the evolution of a } \\
\text { country's aggregate external price } \\
\text { competitiveness. }\end{array}$ & $\begin{array}{l}\text { International Finance Statistics } \\
\text { (IFS) }\end{array}$ \\
\hline $\begin{array}{l}\text { Public sector debt denoted } \\
\text { in foreign currency - } \\
\text { Advanced Economies }\end{array}$ & $\begin{array}{l}\text { OECD only has data for central } \\
\text { government. We assume that } \\
\text { local government debt is mostly } \\
\text { domestic. We therefore } \\
\text { approximate general government } \\
\text { debt denoted in foreign currency } \\
\text { by scaling the foreign currency } \\
\text { share of central government debt } \\
\text { down by the ratio of central } \\
\text { government debt over general } \\
\text { government debt. }\end{array}$ & OECD \\
\hline $\begin{array}{l}\text { Public sector debt denoted } \\
\text { in foreign currency - } \\
\text { Emerging and Low-Income } \\
\text { Economies }\end{array}$ & $\begin{array}{l}\text { External debt stocks, public and } \\
\text { publicly guaranteed, current US\$ }\end{array}$ & $\begin{array}{l}\text { World Bank Global } \\
\text { Development Finance } \\
\text { Database }\end{array}$ \\
\hline $\begin{array}{l}\text { Debt Forgiveness or } \\
\text { Reduction }\end{array}$ & Current US\$ & $\begin{array}{l}\text { World Bank Global } \\
\text { Development Finance } \\
\text { Database }\end{array}$ \\
\hline Banking Crisis & $\begin{array}{l}\text { Dummy variable that takes a } \\
\text { value of } 1 \text { during a banking crisis. }\end{array}$ & $\begin{array}{l}\text { IMF Financial Crisis Episodes } \\
\text { Database (Laeven and } \\
\text { Valencia, 2010) }\end{array}$ \\
\hline $\begin{array}{l}\text { Fiscal Costs of Banking } \\
\text { Crisis }\end{array}$ & Gross, in percent of GDP & $\begin{array}{l}\text { IMF Financial Crisis Episodes } \\
\text { Database (Laeven and } \\
\text { Valencia, } 2010\end{array}$ \\
\hline $\begin{array}{l}\text { Budget Institutions Index - } \\
\text { Transparency Component }\end{array}$ & $\begin{array}{l}\text { Index for } 72 \text { Emerging and Low- } \\
\text { Income Economies }\end{array}$ & $\begin{array}{l}\text { Era Dabla-Norris, Richard } \\
\text { Allen, Felipe Zanna, Tej } \\
\text { Prakash, Victor Lledo, Irene } \\
\text { Yackovlev and Sophia } \\
\text { Gollwitzer (2010). }\end{array}$ \\
\hline $\begin{array}{l}\text { Fiscal Transparency Report } \\
\text { on Observance of } \\
\text { Standards and Codes } \\
\text { (ROSC) }\end{array}$ & Transparency Index & $\begin{array}{l}\text { IMF Fiscal Transparency } \\
\text { Report on Observance of } \\
\text { Standards and Codes (ROSC) } \\
\text { Database }\end{array}$ \\
\hline
\end{tabular}




\section{B. Additional Panel Regressions-Robustness Analysis}

Table A2. Arellano-Bond Dynamic General Methods of Moments Panel Estimator, with the Annual Change in the Debt Level as the Dependent Variable (Percent of GDP)

\begin{tabular}{|c|c|c|}
\hline & Advanced & Emerging and Low-Income \\
\hline \multirow{2}{*}{$\begin{array}{l}\text { Overall Budget Balance (percent of } \\
\text { GDP) }\end{array}$} & -0.69 & -1.46 \\
\hline & $(0.21)^{\star * *}$ & $(0.20)^{\star \star *}$ \\
\hline \multirow[t]{2}{*}{ Inflation } & 0.02 & 0.17 \\
\hline & (0.09) & $(0.37)^{\star * *}$ \\
\hline \multirow[t]{2}{*}{ Valuation effect } & 0.00 & 0.75 \\
\hline & $(0.00)$ & $(0.06)^{* * *}$ \\
\hline $\begin{array}{l}\text { Debt forgiveness or reduction (percent } \\
\text { of GDP) }\end{array}$ & & $\begin{array}{l}-0.23 \\
(0.09)^{\star \star *}\end{array}$ \\
\hline Banking crises & $\begin{array}{c}7.96 \\
(1.40)^{* * *}\end{array}$ & $\begin{array}{c}6.40 \\
(3.30)^{* \star}\end{array}$ \\
\hline Observations & 292 & 1214 \\
\hline Number of countries & 20 & 102 \\
\hline $\begin{array}{l}\text { Arellano-Bond test for } A R(1) \text { in first } \\
\text { differences: }\end{array}$ & $z=-7.15 \operatorname{Pr}>z=0.000$ & $z=-11.43 \operatorname{Pr}>z=0.000$ \\
\hline $\begin{array}{l}\text { Arellano-Bond test for } A R(2) \text { in first } \\
\text { differences }\end{array}$ & $z=1.32 \operatorname{Pr}>z=0.187$ & $z=-0.97 \operatorname{Pr}>z=0.332$ \\
\hline Hansen test of overid. restrictions: & $\begin{aligned} \operatorname{chi} 2(84) & =18.59 \\
\operatorname{Pr}>\operatorname{chi} 2 & =1.000\end{aligned}$ & $\begin{aligned} \text { chi2 } 2(68) & =56.47 \\
\operatorname{Pr}>\text { chi2 } & =0.840\end{aligned}$ \\
\hline
\end{tabular}

Sources: World Economic Outlook; World Bank Global Development Finance Database; OECD; IFS; and IMF Financial Crisis Episodes Database (Laeven and Valencia, 2010).

Note: The dependent variable is measures as the annual change in the net debt level (in percent of GDP) for the advanced economies and as the annual change in the gross debt level (in percent of GDP) for the emerging and low-income economies.

Robust standard errors in parentheses; * denotes significance at 10 percent level; ${ }^{* *}$ denotes significance at 5 percent; ${ }^{* * *}$ denotes significance at 1 percent.

Valuation effect denotes the percentage change in the real effective exchange rate interacted with the public sector debt denoted in foreign currency (in percent of GDP); a positive change denotes exchange rate depreciation.

Debt forgiveness or reduction refer to the total amount of debt that is forgiven or reduced.

In the advanced economies, banking crises denotes the total fiscal costs of a particular banking crisis spread equally over its duration. Banking crises for the emerging and low-income economies, for which detailed data on fiscal costs is not as widely available, is a dummy variable that takes a value of 1 during a banking crisis. In this specification it is assumed that banking crises affect the debt level. However, ex ante it is not clear whether the fiscal costs of banking crises show up in the deficit or the debt level as this depends on an array of issues. This is an important caveat of the above regression since the budget balance is included as an independent variable and could be strongly correlated with the banking crises variable. 


\section{REFERENCES}

Abbas, S.M. Ali, Nazim Belhocine, Asmaa El-Ganainy, and Mark Horton, 2011, "Historical Patterns and Dynamics of Public Debt: Evidence from a New Database," IMF Economic Review, revised and resubmitted.

Arellano, M., and S. Bond, 1991, "Some Tests of Specification for Panel Data: Monte Carlo Evidence and an Application to Employment Equations," Review of Economic Studies, 58, pp. 277-97.

Beetsma R., M. Giuliodori, and P. Wierts, 2009, "Planning to Cheat: EU Fiscal Policy in Real Time," Economic Policy, 60, pp. 753-804.

Campos, C.F.S., D. Jaimovich, and U. Panizza, 2006, “The Unexplained Part of Public Debt," Inter-American Development Bank Working Paper 554 (Washington: InterAmerican Development Bank).

Dabla-Norris, E., R. Allen, L. Zanna, T. Prakash, E. Kvintradze, V. Lledo, I. Yackovlev, and S. Gollwitzer, 2010, "Budget Institutions and Fiscal Performance in Low-Income Countries,” IMF Working Paper 10/80 (Washington: International Monetary Fund).

European Commission, Directorate General for Economic and Financial Affairs, 2003, "Public Finances in EMU 2003" (Brussels: The European Commission).

Hameed, F., 2005, "Fiscal Transparency and Economic Outcomes," IMF Working Paper 05/225 (Washington: International Monetary Fund).

Hausman, J.A., 1978, “Specification Tests in Econometrics,” Econometrica, 46(6), pp. 125171

International Monetary Fund (IMF), 2007, World Economic Outlook, April (Washington: International Monetary Fund).

International Monetary Fund (IMF), 2011a, Fiscal Monitor-Shifting Gears: Tackling Challenges on the Road to Fiscal Adjustment, April (Washington: International Monetary Fund).

International Monetary Fund (IMF), 2011b, Fiscal Monitor-Addressing Fiscal Challenges to Reduce Economic Risks, September (Washington: International Monetary Fund).

Laeven, L., and F. Valencia, 2010, "Resolution of Banking Crises: The Good, the Bad, and the Ugly,” IMF Working Paper 10/146 (Washington: International Monetary Fund).

Von Hagen, J., and G.B. Wolff, 2006, "What Do Deficits Tell Us about Debt? Empirical Evidence on Creative Accounting with Fiscal Rules in the EU," Journal of Banking and Finance, Elsevier, 30 (12), pp. 3259-79. 